\title{
Neuroendocrine excitation in heart failure
}

\author{
A J G Riegger
}

Chronic congestive heart failure (CHF) is a syndrome in which cardiac dysfunction is associated with high morbidity and mortality. Severe symptomatic heart failure is the end point of a lengthy sequence of events, in which the functional state of the left ventricle is an important determinant of the prognosis. As well as the severity of the symptoms of heart failure and the depression of left ventricular ejection fraction, which are independent predictors of survival in heart failure, the neuroendocrine activation found in these patients is directly related to the outcome. It has been shown in controlled trials that one of the most important therapeutic aims to improve survival in patients with chronic CHF must be the inhibition of vasoconstrictor and sodium and water retaining neurohumoral factors. ${ }^{12}$

The table summarises neuroendocrine mechanisms that may be activated in heart failure.

Stimulation of the renin angiotensin-aldosterone system in patients with severe CHF was first described in the $1940 \mathrm{~s}^{3{ }^{34}}$ There is convincing experimental and clinical evidence that neuroendocrine systems are already activated in the very early stages of heart failure and that they interact in different ways in different phases of the disease. ${ }^{56}$ Even when plasma renin activity is within the normal range in early heart failure, there is experimental evidence for at least transient local activation of a renin-angiotensin system within the myocardium-namely, increased messenger RNA for angiotensinogen and angiotensin converting enzyme (ACE).$^{78}$

\section{Neuroendocrine factors in symptomless left ventricular dysfunction}

During the first 72 hours after infarction nearly all neurohumoral factors are increased, but the extent and pattern varies widely. ${ }^{9-11}$ Seven to 10 days later, circulating neurohumoral concentrations have returned to normal in most patients. Nevertheless, in a group of patients with left ventricular dysfunction but no overt heart failure, neurohumoral activation persists. Immediately after infarction sympathetic nervous activity is increased in relation to infarct size and the amount of left ventricular dysfunction. Patients with the highest circulating catecholamines have been found to have the poorest prognosis. ${ }^{12}{ }^{13}$ For 10 days after myocardial infarction the activity of the sympathetic nervous system gradually subsides, even in patients with significant left ventricular dysfunction.
The renin-angiotensin system is activated in nearly all patients early after infarction and rises progressively over the first three days not only in patients with overt heart failure but also in patients with no clinical complications. Increased concentrations of catecholamines, renin, and angiotensin II up to 10 days after admission to hospital were associated with extensive myocardial infarction, low left ventricular ejection fraction, heart failure, ventricular tachycardia, and death. In uncomplicated cases, when diuretics are not used, plasma renin activity gradually returns to normal, so that patients with asymptomatic left ventricular dysfunction have normal plasma renin concentrations at discharge from hospital. ${ }^{914}$

In the survival and ventricular enlargement trial (SAVE) more than 500 patients had plasma neurohumoral concentrations measured at a mean of 12 days after infarction. ${ }^{11}{ }^{15}$ All patients had left ventricular dysfunction (ejection fraction $<40 \%$ ) without overt heart failure. In these patients, all neurohumoral concentrations (plasma renin activity, noradrenaline (norepinephrine), arginine vasopressin, atrial natriuretic peptide) were increased compared with age matched controls. These data show that in a subgroup of patients with significantly reduced left ventricular function at the time of discharge from hospital after an infarction, a persistent neurohumoral activation can be found.

The data contrast with results of the studies of left ventricular dysfunction (SOLVD) prevention group where asymptomatic patients with left ventricular dysfunction (ejection fraction $\leqslant 35 \%$ ) were studied. ${ }^{16}$ Eighty per cent of the patients had had a myocardial infarction $>30$ days previously (mean 3.5 years). In this trial patients had similar plasma noradrenaline concentrations as in the SAVE trial, but had lower plasma renin activity and plasma concentrations of arginine vaso-

Neuroendocrine mechanisms activated in heart failure

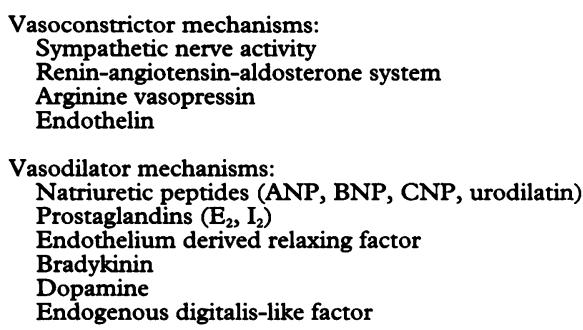

Endogenous digitalis-like factor \\ für Innere M
Universität
Regensburg, Regensburg, Ge Correspondence to:
Professor Dr A J G Riegger, Germany.}


pressin. ${ }^{17}$ These data, and those found in experimental heart failure ${ }^{6}$, show that one of the first neurohumoral factors to be augmented after an injury to the myocardium is atrial natriuretic peptide (ANP), which is predominantly synthesised and secreted from the atria and correlates closely with cardiac dysfunction. ${ }^{18}$ Also, brain natriuretic peptide (BNP), which is highly similar in structure and cardiovascular and renal actions to ANP, was found to be significantly raised in patients after an infarction to a proportionally greater degree than was ANP. ${ }^{19}$ Unlike ANP, BNP is primarily synthesised and secreted from the cardiac ventricles rather than the atria, ${ }^{20}{ }^{21}$ and after an infarction may be a more sensitive and specific indicator of alterations to ventricular function than ANP.

Preliminary data suggest that measurements of circulating BNP may be able to discriminate patients with important left ventricular dysfunction after an acute myocardial infarction, ${ }^{19}$ who should be treated with ACE inhibitors, as it was shown that plasma BNP concentrations were higher in patients with ejection fractions $<40 \%$.

Recently circulating N-terminal ANP has been proposed as a sensitive marker for symptomless left ventricular dysfunction. The ANP is stored as a 126 amino acid prohormone within atrial granules. ${ }^{21} 22$ In response to atrial stretch, the prohormone is cleaved by a membrane protease and released into the circulation as a 28 amino acid C-terminal peptide (C-ANP) and a 98 amino acid N-terminal peptide (N-ANP). ${ }^{23} 24$ As N-ANP has a reduced clearance compared with C-ANP, much higher concentrations of N-ANP can be measured in the circulation.

In a recent study it has been shown that patients with symptomless left ventricular dysfunction can be detected with a much higher sensitivity and specificity by measurement of plasma concentrations of N-ANP than by the determination of C-ANP. ${ }^{25}$ This could have very important implications in the identification of patients with symptomless left ventricular dysfunction in order to start early treatment with ACE inhibitors. This may have an important impact on prognosis.

\section{Neuroendocrine activation in overt heart failure}

In the SOLVD treatment group in which patients with overt mild and moderate heart failure were included (ejection fraction $\leqslant 35 \%$ ) a profound activation of neuroendocrine factors was shown. ${ }^{17} 26$ In contrast with symptomless patients, patients with symptoms have considerably increased plasma renin activity and a further increase in plasma noradrenaline, ANP, and arginine vasopressin.

In patients with severe heart failure (New York Heart Association (NYHA) functional class IV), as was found in the cooperative north Scandinavian enalapril survival study (CONSENSUS), neuroendocrine mechanisms can be excessively active, showing a close association with survival. ${ }^{27}$ Cohn and co-workers investigated the neurohumoral state in more than 600 patients with mild and moderate heart failure (NYHA, functional classes II and III) who participated in the second Veterans Administration cooperative vasodilator-heart failure trial $\left(\mathrm{V}-\mathrm{HeFT}\right.$ II) ${ }^{28}$ and found heterogeneous neurohumoral stimulation without close correlation with clinical variables. ${ }^{29}$

1 Cohn JN, Archibald DG, Ziesche S, Franciosa JA, Harston WE, Tristani FE, et al. Effect of vasodilator therapy on mortality in chronic congestive heart failure: results of a Veterans Administration cooperative study. $N$ Engl f Med 1986;314:1547-52.

2 Swedberg K, Eneroth P, Kjekshus J, Snapinn S, for the CONSENSUS trial Study Group. Effects of enalapril and neurendocrine activation on prognosis in severe and neurendocrine activation on prognosis in severe congestive heart failure (follow-up of
trial). Am f Cardiol 1990;66:40D-5D.

3 Raab W. Adrenocortical compounds in the blood: relation of their quantity to atrial hypertension, renal insufficiency and congestive heart failure. Arch Intern Med 1941;68:713-39.

4 Merril AJ, Morrison L, Brannon ES. Concentration of renin in renal blood in patients with chronic heart failure. Am $\mathcal{F}$ Med 1946;1:468-72.

5 Riegger AJG, Liebau G. The renin-angiotensin-aldosterone system, antidiuretic hormone and sympathetic nerve activity in an experimental model of congestive heart failure in the dog. Clin Sci 1982;62:465-9.

6 Riegger AJG, Elsner D, Kromer EP. Circulatory and renal control by prostaglandins and renin in low cardiac output in dogs. Am $\Im$ Physiol 1989;256:H1079-86.

7 Lindpaintner K, Lu W, Niedermajer N, Schiefer B, Just $\mathrm{H}$, Ganten D, Drexler $\mathrm{H}$. Selective activation of cardiac angiotensin gene expression in post infarction ventricuangiotensin gene expression in post infarction ventricular remodelling

8 Hirsch AT, Talsness CE, Schunkert H, Paul M, Dzau VJ. Tissue-specific activation of cardiac angiotensin converting enzyme in experimental heart failure. Circ Res 1991;69:475-82.

9 McAlpine HM, Morton J, Leckie B, Rumley A, Gillen G Dargie HJ. Neuroendocrine activation after myocardial infarction. Br Heart $\mathcal{f} 1988 ; 60: 117-24$

10 Schaller MD, Nussberger J, Feihl F, Waeber B, Brunner HR, Perret C, Nicod P. Clinical and hemodynamic correlates of elevated plasma arginine vasopressin after acute myocardial infarction. Am $\mathcal{f}$ Cardio 1987;60:1178-80.

11 Rouleau JL, Moyé LA, de Champlain J, Klein M, Bichet $\mathrm{D}$, Packer $\mathrm{M}$, et al. Activation of neurohumoral systems following acute myocardial infarction. Am $\boldsymbol{f}$ Cardiol 1991;68:80D-6D.

12 Valori $C$, Thomas $M$, Shillingford J. Free noradrenaline and adrenaline excretion in relation to clinical syndromes following infarction. Am $f$ Cardiol 1967 20:605-17.

13 Karlsberg RP, Cryer PE, Roberts S. Serial plasma catecholamines response early in the course of clinical acute myocardial infarction: relationship to infarct extent and mortality. Am Heart $\mathcal{F}$ 1981;102:24-9.

14 Vaughan DE, Lamas GA, Pfeffer MA. Role of left ventricular dysfunction in selective neurohumoral activation in the recovery phase of anterior wall acute myocardial the recovery phase of anterior wall acu

15 Pfeffer MA, Braunwald E, Moyé LA, Basta L, Brown EJ, Cuddy TE, et al, on the behalf of the SAVE investigaCuddy TE, et al, on the behalf of the SAVE investiga-
tors. Effect of captopril on mortality and morbidity in patients with left ventricular dysfunction after myocarpatients with left ventricular dysfunction after
dial infarction. $N$ Engl $₹$ Med 1992;327:669-77.

16 The SOLVD investigators. Effect of enalapril on mortality and the development of heart failure in asymptomatic patients with reduced left ventricular ejection fractions. $N$ Engl F Med 1992;327:685-91.

17 Francis GS, Benedict C, Johnstone DE, Kirlin PC Nicklas J, Liang C, et al, for the SOLVD investigators. Comparison of neurendocrine activation in patients with left ventricular dysfunction with and without congestive heart failure. Circulation 1990;82:1724-9.

18 Richards AM, Cleland JFG, Tonolo G, McIntyre GD, Leckie BJ, Dargie HJ, et al. Plasma alpha natriuretic peptide in cardiac impairment. BMF 1986;293:409-12.

19 Motwani JG, McAlpine H, Kennedy N, Struthers AD. Plasma brain natriuretic peptide as an indicator for angiotensin-converting-enzyme inhibition after myocardial infarction. Lancet 1993;341:1109-13.

20 Hosoda K, Nakao K, Mukoyama M, Saito Y, Jougasaki M, Shirakami G, et al. Expression of brain natriuretic $M$, Shirakami G, et al. Expression of brain natriuretic
peptide gene in human heart. Production in the ventricepte. Hypertension 1991;17:1152-5.

21 Mukoyama M, Nakao K, Hosoda K, Suga S, Saito Y, 

Ogawa $\mathrm{Y}$, et al. Brain natriuretic peptides as a novel
cardiac hormone in humans. $\mathcal{F}$ Clin Invest 1991; 87:1402-12.

22 Currie MG, Geller DM, Cole BR, Boylan JG, YuSheng WU, Holmberg $S$, Needleman P. Bioactive cardiac substances: potent vasorelaxant activity in mammalian atria. Science 1983;221:71-3.

23 Pevahouse JB, Martin DR, Trigg DJ, Winters CJ, Vesely DL, Buerkert JE. Prohormone atrial natriuretic peptide $31-67$ as well as atrial natriuretic factor causes a marked natriuresis. Clin Res 1989;37:583.

24 Baker BJ, Wu WCL, Winter CJ, Dinh H, Wyeth R, Sallmann AL, Vesely DL. Exercise increases the circulating concentration of the $\mathrm{N}$-terminal of the atrial natriuretic factor prohormone in normal individuals. $\mathrm{Am}$ Heart f 1991;122:1395-402.

25 Lerman A, Gibbons RJ, Rodeheffer RJ, Bailey KR, McKinley LI, Heublein DM, Burnett JC. Circulating McKinley LJ, Heublein DM, Burnett JC. Circulating symptomless left-ventricular dysfunction. Lancet 1993;

26 The SOLVD investigators. Effect of enalapril on survival in patients with reduced left ventricular ejection fractions and congestive heart failure. $N$ Engl $\mathcal{F} \mathrm{Med}$ 1991;325:293-302.

27 The CONSENSUS Trial Study Group. Effects of enalapril on mortality in severe congestive heart failure. $N$ Engl I Med 1987;316:1429-35.

28 Cohn JN, Johnson G, Ziesche S, Cobb F, Francis G, Tristani F, et al. A comparison of enalapril with hydralazine-isosorbide dinitrate in the treatment of chronic congestive heart failure $N$ Engl $f \mathrm{Med}$ 1991;325:303-10.

29 Cohn IN, Johnson G, Francis GS, and the Veterans Administration Study Group. Sympathetic and renin stimulation in heart failure: the absence of homogeneity in S-HeFT II. Circulation 1990;82(suppl III):382 A. 